\author{
Ана С. БАТАС ${ }^{*}$ \\ Филолошки факултет \\ Универзитета у Београду
}

\title{
ДИСТИНКТИВНА ОБЕЛЕЖЈА ГЛАВНИХ КЛАСА ${ }^{* *}$
}

\begin{abstract}
У овом раду бавимо се обележјима главних класа као што су сонорност, апроксимантност, силабичност, консонантност и начинима на које се та обележја могу применити на фонолошки систем српског језика.
\end{abstract}

Кључне речи: фонологија, дистинктивна обележја, сонорност, апроксимантност, силабичност, консонантност, српски језик.

\section{1. Увод}

1.1. Под дистинктивним обележјима (у даљем тексту ДО или обележје) којима се бавимо у овом раду подразумевају се она обележја којима се гласови класификују у „главне класе”, као што су вокали, консонанти, опструенти и сонанти (Траск 1996: s. v. MAJOR-CLASS FEATURE), односно она која се користе за опонирање главних класа фонема. Овим радом надовезујемо се на претходно објављене радове у којима смо се бавили обележјима везаним за место артикулације (Батас 2018) и обележјима везаним за начин артикулације (Батас 2019).

1.2. Теорија ДО Р. Јакобсона, М. Халеа и Г. Фанта (у даљем тексту ПСА), којом се свако ДО дефинише помоћу акустичких и артикулационих особина фонема којима се дато обележје приписује, највише је утицала на сербокроа-тистичке, а касније србистичке и кроатистичке радове, махом објављене у другој половини 20. века: Јакобсон 1949/1964, Муљачић 1964, Брозовић

\footnotetext{
*anabatas@fil.bg.ac.rs

** Овај рад урађен је у оквиру пројекта „Српски језик и његови ресурси: теорија, опис и примене”, бр. 178006, који финансира Министарство просвете, науке и технолошког развоја Републике Србије.
} 
1968, 1971, Симић/Остојић 1996, Барић et al. 1997, Петровић 2000, Петровић/Гудурић 2010. У чувеној монографији Н. Чомског и М. Халеа The Sound Pattern of English (у даљем тексту СПЕ) изнете су поставке генеративне фонологије, теорије која је значајно утицала на развој те дисциплине у другој половини 20. века, а која скоро да није оставила никаквог трага у србистичким радовима из те области. Обе поменуте теорије сврставају се у тзв. линеарне фонолошке теорије, а насупрот њима, теорије попут аутосегменталне теорије сврставају се у нелинеарне и заснивају се на претпоставци да постоје различити нивои одн. редови (енгл. tiers) фонолошке репрезентације помоћу којих се приказују појаве које се протежу на више сегмената (в. Клементс/ Хјум 1996). Н. Клементс и Е. Хјум (idem: 182) као једну од главних слабости линеарних теорија издвајају наводну немогућност исказивања хијерархије међу обележјима, као и непостојање начина да се обележја групишу у тзв. „природне класе”, што је идеја која датира још од Николаја Трубецког $(1958 / 2016)^{1}$.

\section{2. Фонетски опис ДО}

Представљање обележја главних класа започећемо од обележја вокалност и силабичност, која се у различитим матрицама наизменично јављају. Као што ћемо видети, дефиниције ових обележја потпуно се разликују, али их повезује то што се њима углавном упућује на исте сегменте 2 .

Када се описују артикулационе особине сегмената који имају обележје вокалност, најчешће се наводи релативно слободан проток фонационе струје кроз канал ${ }^{3}$ који није ужи од канала високих вокала ${ }^{4}$, а налази се у средини усне дупље (СПЕ: 302). Од акустичких особина ових сегмената на спектрограмима се јасно могу приметити прва три форманта релативно уских појасева (ПСА: 19). ${ }^{5}$ За Н. Чомског и М. Халеа у вокалске сегменте спадају вокали

\footnotetext{
${ }^{1}$ Са критиком Н. Клементса и Е. Хјума (1996: 182) само се делимично слажемо, о чему смо више писали у раду Батас 2019.

${ }^{2}$ Сегмент користимо да њиме означимо и фонеме и алофоне. Док се у ПСА обележја користе да се њима направи дистинкција међу фонемама, у СПЕ било који глас, па чак и онај који нема дистинктивну функцију у конкретном фонолошком систему, може бити опониран (контрастиран) другом гласу помоћу неког обележја.

${ }^{3}$ Термин канал користимо да бисмо избегли термине сужење и теснац, који се односе на тип препреке која настаје при изговору фрикатива. При изговору вокала, језик и положај усана обликују усну дупљу у канал или цев одређеног облика (дужине и попречног пресека). У зависности од облика канала (резонатор) мења се вокалска боја, па ће тако цев која је дугачка а уска појачавати ниже фреквенције.

${ }^{4}$ Н. Чомски и М. Хале претпостављају да приликом изговора вокалских сегмената долази до спонтаног звучања (СПЕ: 300-302). Разликују спонтану звучност код вокала и сонаната од звучности код опструената, која није спонтана. Спонтаном звучношћу објашњавају зашто вокали и сонанти углавном не учествују у асимилацији по звучности. Њихову идеју даље развија В. Јансен $(2004,2007)$, тврдећи да су неке класе опструената (правих консонаната) активно звучне - изговарају се или помоћу артикулационих покрета којима се поништавају ефекти пасивног обезвучавања, или помоћу артикулационих покрета који снижавају минимални трансглотани притисак неопходан за рад гласних жица; друге опструенте убраја у активно безвучне, зато што умањују ефекте пасивне звучности.

${ }^{5}$ У литератури се прецизира и да се прва три форманта налазе испод $3200 \mathrm{~Hz}$ за мушке гласове и да је интензитет нижих форманата већи, што не мора бити перцептивно битно (ПСА: 19).
} 
и ликвиде, а у невокалске - опструенти, глајдови (= полувокали) и назали (СПЕ: 302).

Силабичност је једино обележје које се не дефинише на основу артикулационих и акустичких карактеристика, већ на основу функције сегмената у слогу. Као што саิм назив каже, силабички сегменти дефинишу се као сегменти који су носиоци слога (слоготворни), одн. као они који се налазе у језгру/нуклеусу слога. Н. Чомски и М. Хале користили су ово обележје искључиво да њиме направе дистинкцију између високих вокала и глајдова, нпр. између /i/ и /j/. Брус Хејз сматра пак да је неопходно да силабичност постоји као засебно обележје, јер - иако је чињеница да се у огромној већини слогова у језгру налази вокал - постоје језици у којима се могу наћи слоготворне ликвиде или назали, а у такве језике спада и српски (Хејз 2009: 77). Од увођења теорија слога у генеративну фонологију, многи фонолози су сматрали да је силабичност сувишно обележје, јер се на основу улоге коју одређени сегмент игра у слогу одређује да ли је неки вокоид - глајд или вокал. Са таквим се становиштем не слаже Џ. Паџет и сматра да се вокали од глајдова морају разликовати управо помоћу овог обележја (Паџет 2008).

Под консонантношћу се сматра обележје које је везано за консонанте, гласове произведене уз препреку у мидсагиталној (средишњој) регији вокалног тракта. ${ }^{6}$ У наставку прецизирају да препрека мора бити уска најмање колико и сужење које се формира при артикулацији фрикатива. Ово обележје разликује ликвиде, назалне сонанте и опструенте од вокала и глајдова (СПЕ: 302).

Под сонорношћy се подразумева обележје које се везује за оне сегменте изговорене помоћу препреке која допушта да ваздушни притисак иза и испред ње буде изједначен (Гусенховен/Џејкобс 2017: 67). ${ }^{7}$ Другим речима, када се при изговору гласа формира значајна препрека, ваздушни притисак расте, а то даље доводи до појаве шума након отпуштања препреке; на тај начин настају [-сонорни $]^{8}$ сегменти. Када се при изговору гласа формира препрека која не доводи до раста ваздушног притиска (или се пак не формира никаква препрека), настају [+сонорни] сегменти. У сонорне гласове убрајају се вокали и сонанти, а сви опструенти спадају у [-сонорни].

Поједине групе гласова имају вишу сонорност од других: што је ефекат резонанције већи - то је глас сонорнији. Код вокала је ефекат резонанције већи због релативно слободног тока фонационе струје, па су сви вокали сонорнији од сонаната, а скала сонорности опада од вокала према опструентима на следећи начин: вокали $>$ глајдови $>$ ликвиде $>$ назали $>$ опструенти. Хијерархија гласова по сонорности важна је за теорије слога засноване на принципу да се гласови ређају према скали сонорности, од језгра, које садржи најсонорнији глас, ка периферији, где се налазе мање сонорни гласови.

\footnotetext{
${ }^{6}$ Чомски и Хале описују препреку као значајну (радикалну). Ипак, сматрамо да се под значајном препреком може подразумевати само она препрека којом се артикулишу опструенти (в. даље).

${ }^{7}$ У СПЕ под сонорним сегментима подразумевају се они код којих је могућа спонтана звучност (в. изнад).

${ }^{8}$ Термини традиционалне фонетике: иумни консонанти, прави консонанти, консонанти у ужем смислу; а термин модерне фонетике: опструенти.
} 


\begin{tabular}{|c|c|c|c|c|c|c|}
\hline$\approx$ & + & & + & & & \\
\hline 0 & + & & $\mathrm{H}$ & + & & \\
\hline 0 & + & & $\mathrm{H}$ & 1 & & \\
\hline$=$ & + & & 1 & + & & \\
\hline$\neg$ & + & & 1 & 1 & & \\
\hline$=$ & H & & + & & + & \\
\hline- & H & & 1 & & + & \\
\hline- & $H$ & & & & 1 & \\
\hline$\simeq$ & & + & + & & & \\
\hline$\Xi$ & & + & 1 & + & & \\
\hline$=$ & & + & 1 & 1 & & \\
\hline$x$ & & & + & + & + & \\
\hline Do & & & + & + & & + \\
\hline$\breve{v}$ & & & + & + & 1 & 1 \\
\hline $\mathrm{NN}$ & & & + & & + & + \\
\hline in & & & + & 1 & + & 1 \\
\hline סמי & & & + & & H & + \\
\hline ני & & & + & & $H$ & 1 \\
\hline+ & & 1 & + & 1 & 1 & + \\
\hline .0. & & & + & 1 & 1 & 1 \\
\hline$>$ & & & & + & + & + \\
\hline$\omega$ & & & 1 & + & + & 1 \\
\hline م & & 1 & 1 & + & 1 & + \\
\hline 2 & & & 1 & + & 1 & 1 \\
\hline $\mathrm{N}$ & & & 1 & 1 & + & + \\
\hline$n$ & & & 1 & 1 & + & 1 \\
\hline 0 & & & 1 & & H & \\
\hline$\tau$ & & 1 & 1 & 1 & 1 & + \\
\hline- & & & 1 & 1 & 1 & 1 \\
\hline & 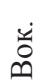 & జ் & 离 & 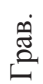 & $\begin{array}{l}\dot{H} \\
\text { 它 }\end{array}$ & 宮 \\
\hline
\end{tabular}




\section{3. Матрице ДО}

\section{1. Р. Јакобсон $(1949 / 1964)$}

Табелом 1 представљамо матрицу ДО Р. Јакобсона за српски језик.

Под апроксимантношћу се подразумева обележје које се везује за сегменте код којих фонациона струја успева да превазиђе или заобиђе препреку без значајних промена. На акустичком плану, као последица таквог, релативно неометаног протока фонационе струје, појављује се формантска структура. Овим обележјем групишу се вокали, глајдови и ликвиде као сегменти са обележјем [+апроксимантност] и назални сонанти и опструенти са обележјем [-апроксимантност] (Хол 2007: 314). При артикулацији назалних сонаната, фонациона струја се цепа на два крака. Крак који пролази кроз носну дупљу пролази слободно, док крак фонационе струје који пролази кроз усну дупљу наилази на потпуну препреку (преграду), каква се јавља код експлозива.

За сврставање фонема у главне класе, Р. Јакобсон користи само обележје вокалност, и то тако што [+вокалност] везује за вокале, [ \pm вокалност] за ликвиде, што значи да ликвиде, за разлику од вокала, немају обележје вокалност у пуној мери. Остали консонанти немају обележје вокалност. Фонеме /j/ нема у табели, па се може закључити да ју је посматрао као један од алофона фонеме /i/. Фонему /v/ убраја пак у фрикативе.

У табели су дати редом називи обележја: 1. вокалски, 2. шумни, 3. компактни, 4. дифузни, 5. акутски, 6. назални, 7. континуирани, 8. звучни, 9. стридентни, 10. напети. Д. Брозовић у матрици обележја наводи и ДО вокалност и ДО шумност (консонантност). Вокалима и фонеми /j/ приписује [+вокалност], а [-вокалност] приписује свим осталим консонантима. Обележје [+консонантност] имају само опструенти, док сонанти, осим фонеме /j/, имају [-консонантност]. Назални и орални сонанти подељени су у засебне класе (5. и 6. класу). У матрици из 1968. године, коју због недостатка простора нећемо наводити, Д. Брозовић је за прво обележје у матрици истакао консонантност (његов термин је шумност), па су сви сонанти и вокали добили ДО [-консонантност], а на друго место поставио је ДО вокалност, због чега су вокали (и /j/) добили [+вокалност], а сонанти [-вокалност]. 


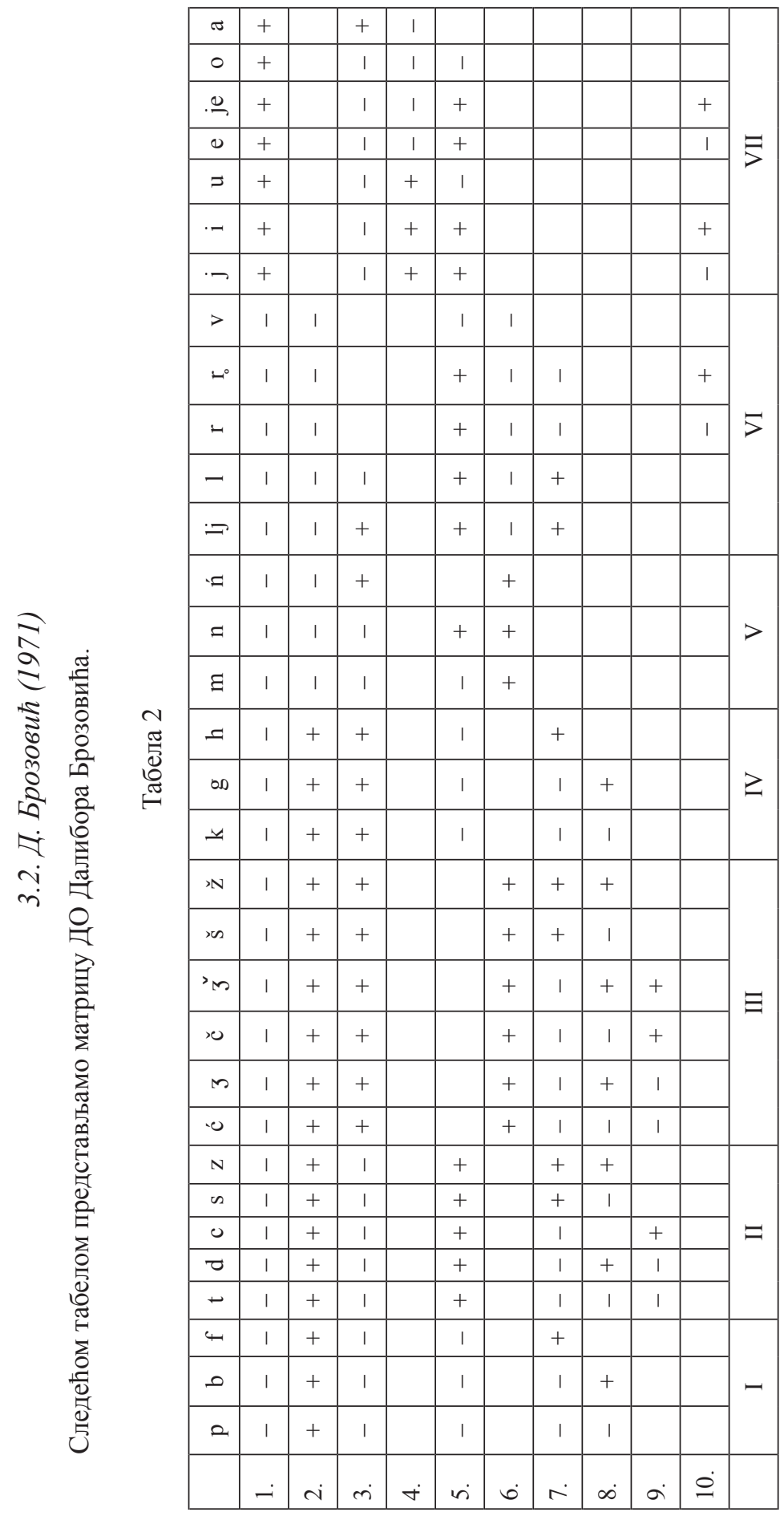




\section{3. Р. Симић и Б. Остојић (1996)}

Следећом табелом представљамо матрицу којом су Р. Симић и Б. Остојић представили ДО за сонанте српског језика. Због уштеде простора не приказујемо матрице ДО за остале групе фонема.

\section{Табела 3}

\begin{tabular}{|l|c|c|c|c|c|c|c|c|}
\hline & $\mathrm{j}$ & $\mathrm{v}$ & $\mathrm{r}$ & $\mathrm{l}$ & $\mathrm{lj}$ & $\mathrm{m}$ & $\mathrm{n}$ & $\mathrm{nj}$ \\
\hline ламинарност & + & + & + & + & + & + & + & + \\
\hline назалност & - & - & - & - & - & + & + & + \\
\hline абруптност & - & - & + & - & - & + & + & + \\
\hline акутност & + & - & + & + & + & - & + & + \\
\hline грависност & - & + & - & - & - & + & - & - \\
\hline дифузност & + & + & - & - & + & + & - & + \\
\hline турбулентност & + & + & - & - & - & - & - & - \\
\hline
\end{tabular}

Р. Симић и Б. Остојић за вокале и сонанте везују обележје периодичност, под којим подразумевају да је „глас састављен од периодичних фреквенци (форманата)”, односно да при артикулацији гласа „ваздух у коморама слободно резонира" (Симић/Остојић 1996: 142, 198). За сонанте везују обележје ламинарност, чију артикулациону страну описују као локализираност изговора, под чиме подразумевају да се у усној дупљи јављају препреке, али да оне не утичу битније на ток фонационе струје (idem: 143). У домену акустике, ламинарност описују као лонгитудинални ток фонационе струје (ibid.). Сонантима /j/ и /v/ приписују обележје [+турбулентност], што је неочекивано решење, будући да турбулентост на акустичком плану описују као „снажна трансверзална кретања која ометају основни лонгитудинални проток фонације" (ibid.). Назалним сонантима и фонеми /r/ приписују обележје абруптности, што је у складу са бројим класификацијама гласова у којима се назални сонанти групишу заједно са експлозивима у групу оклузивних (зауставних) гласова.

Занимљиво је да Р. Симић и Б. Остојић термин „сонорност” користе уместо термина „звучност”, што се може видети и из кратког описа обележја сонорност када кажу да је „глас озвучен тј. фонациона струја је праћена примарним тоном”, односно када кажу да „при творби гласа трепере гласне жице” (Симић/Остојић 1996: 142).

\section{3. Барuћ et al. (1997)}

Табелом 4 представљамо матрицу ДО према Барић et al. 1997. 


\begin{tabular}{|c|c|c|c|c|c|c|c|c|c|c|c|}
\hline$=$ & + & । & 0 & + & + & 0 & 0 & 1 & 0 & 0 & 0 \\
\hline 0 & + & 1 & 0 & 1 & + & 0 & 0 & 0 & 0 & 0 & 0 \\
\hline$\sigma$ & + & 1 & + & 1 & 1 & 0 & 0 & 0 & 0 & 0 & 0 \\
\hline$\stackrel{\mathscr{2}}{\mathscr{2}}$ & + & 1 & 1 & 1 & 1 & + & 0 & 0 & 0 & 0 & + \\
\hline 0 & + & 1 & 1 & 1 & 1 & + & 0 & 0 & 0 & 0 & 1 \\
\hline. & + & 1 & 1 & + & I & + & 0 & 0 & 0 & 0 & + \\
\hline$\rightarrow$ & 1 & 1 & + & 0 & 1 & + & 0 & 0 & 0 & 0 & 1 \\
\hline$\because 0$ & 1 & 1 & 0 & 0 & 0 & 0 & 1 & 1 & 0 & 0 & + \\
\hline-1 & 1 & 1 & 1 & 0 & 0 & 0 & 1 & 1 & 0 & 0 & 1 \\
\hline$=$ & 1 & 1 & + & 0 & 0 & 0 & 1 & + & 0 & 0 & 0 \\
\hline- & 1 & 1 & 1 & 0 & 0 & 0 & 1 & + & 0 & 0 & 0 \\
\hline$\because$ & 1 & 1 & + & 0 & 1 & 0 & + & 0 & 0 & 0 & 0 \\
\hline$\Rightarrow$ & 1 & 1 & 1 & 0 & I & + & + & 0 & 0 & 0 & 0 \\
\hline$\Xi$ & 1 & 1 & 1 & 0 & + & 0 & + & 0 & 0 & 0 & 0 \\
\hline$>$ & I & I & 1 & 0 & + & 0 & 1 & 0 & 0 & 0 & 0 \\
\hline NN & 1 & + & + & 0 & 1 & + & 0 & + & + & 0 & 0 \\
\hline $\mathrm{N}$ & 1 & + & 1 & 0 & 1 & + & 0 & + & + & 0 & 0 \\
\hline ᄃ & । & + & + & 0 & 0 & 0 & 0 & + & 0 & 1 & 0 \\
\hline$\infty n$ & 1 & + & + & 0 & 1 & + & 0 & + & 1 & + & 0 \\
\hline n & 1 & + & I & 0 & 1 & + & 0 & + & 1 & 0 & 0 \\
\hline 4 & I & + & । & 0 & + & 0 & 0 & + & 0 & 0 & 0 \\
\hline$m$ & 1 & + & + & 0 & 1 & + & 0 & 1 & + & 1 & 0 \\
\hline$m$ & I & + & + & 0 & 1 & + & 0 & 1 & + & + & 0 \\
\hline 0 & I & + & + & 0 & 1 & + & 0 & 1 & 1 & 1 & 0 \\
\hline 0 & 1 & + & + & 0 & 1 & + & 0 & 1 & 1 & + & 0 \\
\hline 0 & 1 & + & 1 & 0 & 1 & + & 0 & 1 & 0 & + & 0 \\
\hline an & 1 & + & + & 0 & 0 & 0 & 0 & 1 & + & 0 & 0 \\
\hline$\tau$ & 1 & + & 1 & 0 & 1 & + & 0 & 1 & + & 0 & 0 \\
\hline م & 1 & + & 1 & 0 & + & 0 & 1 & 1 & + & 0 & 0 \\
\hline$\not y$ & 1 & + & + & 0 & 0 & 0 & 0 & 1 & 1 & 0 & 0 \\
\hline- & 1 & + & 1 & 0 & 1 & + & 0 & 1 & 1 & 0 & 0 \\
\hline \multirow[t]{2}{*}{2} & I & + & 1 & 0 & + & 0 & 0 & I & 1 & 0 & 0 \\
\hline & 峁 & 完 & $\sum_{0}^{\dot{\theta}}$ & 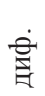 & 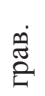 & 宾 & 番 & $\begin{array}{l}\dot{1} \\
\text { 品 }\end{array}$ & 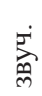 & $\begin{array}{l}\dot{\vec{J}} \\
\dot{\vec{b}} \\
\dot{J}\end{array}$ & 离 \\
\hline
\end{tabular}




\begin{tabular}{|c|c|c|c|c|c|c|c|c|}
\hline$\Rightarrow$ & + & 1 & 1 & 1 & 1 & 1 & + & + \\
\hline$\beth^{n}$ & + & + & 1 & 1 & 1 & I & + & + \\
\hline 工 & + & I & 1 & 1 & + & 1 & 1 & + \\
\hline$\cdot \rightarrow$ & 1 & | & 1 & 1 & 1 & 1 & + & + \\
\hline- & + & + & + & 1 & 1 & 1 & + & + \\
\hline- & + & + & + & I & 1 & 1 & + & + \\
\hline ad & + & 1 & 1 & 1 & + & 1 & + & 1 \\
\hline$\not 4$ & + & I & 1 & 1 & + & 1 & 1 & 1 \\
\hline $2 \mathrm{~N}$ & + & I & 1 & 1 & 1 & 1 & + & + \\
\hline in & + & | & 1 & 1 & 1 & 1 & 1 & + \\
\hline 0 & + & 1 & 1 & 1 & I & 1 & 1 & 1 \\
\hline$m$ & + & I & 1 & I & 1 & I & + & 1 \\
\hline 0 & + & 1 & 1 & 1 & 1 & 1 & 1 & I \\
\hline${ }_{\mathrm{N}}$ & + & 1 & 1 & 1 & 1 & 1 & + & 1 \\
\hline טי & + & I & 1 & 1 & 1 & 1 & 1 & 1 \\
\hline$=$ & + & I & + & 1 & I & 1 & + & 1 \\
\hline $\mathbf{N}$ & + & I & + & 1 & I & I & + & + \\
\hline in & + & I & + & 1 & I & 1 & 1 & + \\
\hline$\nabla$ & + & I & + & 1 & I & 1 & + & 1 \\
\hline$\leftarrow$ & + & I & + & 1 & I & 1 & I & I \\
\hline$\Xi$ & + & I & + & 1 & + & 1 & + & 1 \\
\hline$>$ & + & I & + & 1 & + & 1 & + & + \\
\hline 4 & + & I & + & 1 & + & 1 & 1 & + \\
\hline مـ & + & I & + & 1 & + & 1 & + & 1 \\
\hline 2 & + & 1 & + & 1 & + & 1 & 1 & 1 \\
\hline & 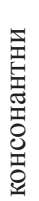 & 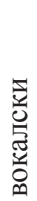 & 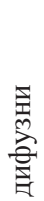 & 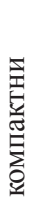 & 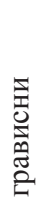 & 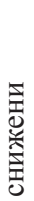 & 褊 & 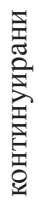 \\
\hline
\end{tabular}




\section{4. Д. Кристал (1999)}

Табелом 5 представљамо матрицу ДО која се налази у српском преводу Кембричке енциклопедије језика Д. Кристала.

Слично као у матрици ДО Д. Брозовића, код Е. Барић обележје [+консонантност] имају само опструенти. Међутим, за разлику од матрице Д. Брозовића, у овој матрици сви сонанти, укључујући и фонему /j/, имају [-консонантност]. Обележје [+вокалност] везује се само за вокале, док сонанти и опструенти имају обележје [-вокалност]. Може се закључити да је кључна разлика између примене обележја главних класа код Д. Брозовића и Е. Барић статус фонеме /j/.

У матрици ДО за српски језик дата су обележја и консонантност и вокалност. Обележје [+консонантност] везује се за све консонанте осим фонеме /j/, док се [+вокалност] везује за вокале, који се налазе у засебној табели, и ликвиде. Обележје [-вокалност] имају сви опструенти, међу које је убрајана и фонема $/ v /$, назали и фонема $/ \mathrm{j} /$. Може се претпоставити да је вокалност изједначена са силабичношћу у горњој матрици.

\section{4. Д. Петровић (2000)}

Табелом 6 представљамо матрицу ДО Д. Петровића објављену у Петровић 2000. Слична матрица објављена је и у Петровић/Гудурић 2010 , а једина разлика међу њима јесте то што се у каснијој верзији уместо „нула” налазе „белине”.

Д. Петровић уместо ДО консонантност уводи ДО сонорност и поставља га на друго место, иза обележја вокалност. Обележје сонорност користи да њиме направи дистинкцију између консонанта који на акустичком плану имају чист шум (опструената) и консонаната који су комбинација тона и шума (сонаната). На артикулационом плану разликују се консонанти настали помоћу потпуне преграде протоку фонационе струје од консонаната који су настали помоћу делимичне преграде (Петровић 2000: 793-794). Оваква интерпретација обележја сонорност није уобичајена у савременим фонолошким теоријама, јер се, као што смо већ видели, овим обележјем углавном обухватају и вокали и сонанти.

Д. Петровић [+вокалност] приписује, очекивано, вокалима, док сонантима за то обележје додељује „нуле”. Опструенти имају пак ДО [-вокалност]. Обележје [+сонорност], као што следи из његове дефиниције обележја, додељено је сонантима, док вокали имају у матрици „нуле”, а опструенти обележје [-сонорност]. 


\begin{tabular}{|c|c|c|c|c|c|c|c|c|c|}
\hline$x$ & 1 & 1 & & + & & + & 1 & + & \\
\hline$\cdot \rightarrow$ & 1 & 1 & & + & & + & 1 & 1 & \\
\hline 目 & 1 & I & & + & & + & + & 1 & 1 \\
\hline 次 & I & 1 & & + & & + & + & 1 & + \\
\hline 0 & 1 & I & & 1 & & + & 0 & 1 & 1 \\
\hline$m$ & 1 & 1 & & 1 & & + & 0 & 1 & + \\
\hline$=$ & 1 & 1 & & 1 & & + & 0 & + & 1 \\
\hline 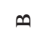 & 1 & 1 & & 1 & & + & 0 & + & + \\
\hline $\mathscr{y}$ & 1 & 1 & & + & & 1 & 1 & + & 1 \\
\hline L & 1 & | & & + & & | & 1 & + & + \\
\hline$F$ & 1 & 1 & & + & & 1 & + & I & 1 \\
\hline$\exists$ & 1 & 1 & & + & & 1 & + & 1 & + \\
\hline L & 1 & 1 & & + & & 1 & 1 & 1 & 1 \\
\hline ta & 1 & 1 & & + & & | & 1 & 1 & + \\
\hline$\exists$ & 1 & 1 & & 1 & & 1 & + & 1 & \\
\hline$H$ & 1 & 1 & & 1 & & 1 & 1 & 1 & 1 \\
\hline$\exists$ & 1 & 1 & & 1 & & 1 & 1 & 1 & + \\
\hline E & 1 & 1 & & 1 & & 1 & 1 & + & 1 \\
\hline 10 & 1 & 1 & & 1 & & I & 1 & + & + \\
\hline ค & 0 & + & I & + & & 0 & & I & 0 \\
\hline 由 & 0 & + & + & + & & 0 & & 1 & 0 \\
\hline 2 & 0 & + & 1 & 1 & & 1 & & 1 & 0 \\
\hline$\curvearrowleft$ & 0 & + & 1 & 1 & & + & & 1 & 0 \\
\hline$I$ & 0 & + & + & I & & 0 & & 1 & 0 \\
\hline$\Sigma$ & 0 & + & + & 1 & & 0 & & + & 0 \\
\hline$\lambda$ & + & 0 & & 1 & + & 0 & & + & 0 \\
\hline 0 & + & 0 & & 1 & 1 & 0 & & + & 0 \\
\hline$\pi$ & + & 0 & & + & 1 & 0 & & 1 & 0 \\
\hline 0 & + & 0 & & 1 & 1 & 0 & & 1 & 0 \\
\hline$\Xi$ & + & 0 & & 1 & + & 0 & & 1 & 0 \\
\hline & نั & ذ્ذ & $\underset{\mathbb{Z}}{\ddot{\Xi}}$ & $\sum_{0}^{\dot{B}}$ & 完 & 苗 & $\begin{array}{l}\dot{-} \\
\stackrel{\Xi}{0} \\
\dot{0}\end{array}$ & $\begin{array}{l}\stackrel{\otimes}{\tilde{Z}} \\
\stackrel{2}{L}\end{array}$ & $\overbrace{m}^{\dot{m}}$ \\
\hline
\end{tabular}




\section{4. Могућа систематизација}

Следећом табелом представљамо један од начина на који се гласови могу сврстати у главне класе: вокале, полувокале, ликвиде, назале и опструенте. Као што се из табеле може видети, уместо јединствене класе сонаната, која би објединила полувокале, ликвиде и назале, представљене су подгрупе сонаната у истој равни са вокалима и опструентима. Ниједно од наведених обележја узето само за себе није дискриминативно за сонанте, већ их нека повезују са вокалима, а друга са опструентима.

Табела 7 (рађена према табели Б. Хејза (2009: 76))

\begin{tabular}{|c|c|c|c|c|}
\hline ВОКАЛИ & ПОЛУВОКАЛИ & ликВидЕ & НАЗАЛИ & ОПСТРУЕНТИ \\
\hline [+силабичност] & \multicolumn{4}{|c|}{ [-силабичност] } \\
\hline \multicolumn{2}{|c|}{ [-консонантност] } & & \multicolumn{2}{|c|}{ [+консонантност] } \\
\hline \multicolumn{3}{|c|}{ [+апроксимантност] } & \multicolumn{2}{|c|}{ [-апроксимантност] } \\
\hline \multicolumn{4}{|c|}{$[+$ сонорност $]$} & {$[-$-сонорност $]$} \\
\hline
\end{tabular}

Једино обележје које обухвата све сонанте, али и све вокале јесте сонорност. Пошто се оно обично везује за сегменте изговорене без релевантне препреке, односно без препреке која би довела до пораста ваздушног притиска, $[+$ сонорност] везујемо за вокале и сонанте, а [-сонорност] за опструенте. Захваљујући оваквој дефиницији обележја, асимилацију по звучности (једначење сугласника по звучности), могуће је једноставно описати следећим формулама традиционалне генеративне фонологије:

a) регресивна асимилација безвучних опструената (озвучавање) $[-$ сонорни, - звучни $] \rightarrow[+$ ввучни $] /[$ _ $[-$ сонорни, + +звучни $]$

б) регресивна асимилација звучних опструената (обезвучавање) $[-$ сонорни, +звучни $] \rightarrow[-3$ вучни $] / \ldots$ [-сонорни, -3 вучни $]$

Вокале од сонаната раздвајамо обележјем силабичност, па се за вокале везује [+силабичност], а за сонанте [-силабичност]. Поједини сонанти у српском језику могу бити слоготворни, као што је /r/ у домаћим речима (pm,

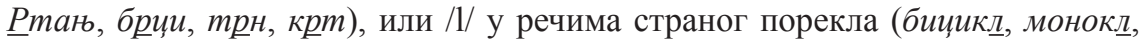
Влтава), али као што је већ речено, они постају слоготворни када су најсонорнији сегмент у слогу, тј. кад у датом слогу нема вокала (или када је иза $/ \mathrm{r} /$ вокал /o/ који је алтернирао са $/ 1 /$, као у примеру умро). Према томе, сонанти би се као јединствена група могли представити помоћу два обележја - [+сонорност] и [-силабичност], уз горњу ограду везану за ликвиде у слоготворној функцији.

Пошто под консонантношћу подразумевамо обележје које се везује за сегменте настале помоћу препреке у средишњем делу усне дупље, обележје 
[-консонантност] везује се за вокале и полувокале. Ипак, потребно је додати да /j/ и /v/ по многим особинама не припадају истој групи. Лабиодентални апроксимант /v/ у српском језику не спада у фрикативе, нити је парњак фонеме /f/, што је више пута у радовима доказивано, било теоријски из синхронијске и дијахронијске перспективе (Белић 2000), било експериментално (Бјорндал 2018). За разлику од енглеског билабијалног полувокала /w/, који је по свим артикулационим и акустичким особинама спада у типичне полувокале, српски лабиодентални сонант /v/ у неким позицијама, а посебно иницијалној, знатно се по акустичким и артикулационим особинама приближава звучном фрикативу /v/. Ако би се издвојио из групе полувокала као што је приказано у табели 8 , лабиодентални апроксимант би са ликвидама чинио засебну групу са обележјем [+консонантност].

Табела 8

\begin{tabular}{|c|c|c|c|c|c|}
\hline \multicolumn{4}{|c|}{ [+апроксимантност] } & \multirow{2}{*}{\multicolumn{2}{|c|}{ [-апроксимантност] }} \\
\hline \multicolumn{2}{|c|}{ [-консонантност] } & \multicolumn{2}{|c|}{ [+консонантност] } & & \\
\hline $\begin{array}{c}\text { вокали } \\
/ \mathrm{i}, \mathrm{e}, \mathrm{a}, \mathrm{o}, \mathrm{u} /\end{array}$ & $\begin{array}{c}\text { полувокали } \\
\text { /j/ }\end{array}$ & $\begin{array}{c}\text { „неликвиде” } \\
\text { /v/ }\end{array}$ & $\begin{array}{c}\text { ликвиде } \\
/ \mathrm{r}, 1, \Lambda /\end{array}$ & $\begin{array}{l}\text { назали } \\
/ \mathrm{m}, \mathrm{n}, \mathrm{p} /\end{array}$ & опструенти \\
\hline
\end{tabular}

Но, таква класификација у овом тренутку није оправдана, јер би се морали наћи докази да фонеме /j/ и /v/ имају различите функције у слогу, да се различито понашају у фонолошким алтернацијама и слично.

Ако се вратимо на традиционалну поделу приказану у табели 7, видећемо да је вокале и опструенте могуће дефинисати преко једног обележја: за вокале се везује обележје [+силабичност], а за опструенте - обележје [-сонорност]. Полувокали се морају пак дефинисати преко два обележја [-силабичност, -консонантност], па се тиме разликују од вокала, са једне, и од ликвида, са друге стране. Ликвиде се такође морају дефинисати на основу два обележја [+апроксимантност, +консонантност]. Првим од њих разликују се од назала, који се због потпуне препреке, тј. преграде, у усној дупљи, не би могли наћи у истој групи са осталим апроксимантним сонантима. Ликвиде се од полувокала разликују на основу обележја [+консонантност]. Назале је такође неопходно дефинисати преко два обележја [-апроксимантност, + сонорност], уколико се у матрици не користи обележје [+назалност]. Првим обележјем разликују се од ликвида, а другим од опструената, који имају обележје [-сонорност].

Другим речима, обележје сонорност обједињује вокале и сонанте и супротставља их опструентима. Пошто сонорне фонеме не условљавају асимилацију по звучности (једначење сугласника по звучности), нити алтернирају могућим безвучним парњацима, могло би се претпоставити да би се у хијерархији ДО сонорност нашла изнад звучности. И у већини досадашњих матрица на исти начин се поступало, па обележје звучност или нема никак- 
вог предзнака (нпр. Јакобсон 1949/1964, Брозовић 1971) или одређене групе фонема имају „нуле”, што би значило да за те групе фонема обележје није спецификовано (нпр. Барић et al. 1997, Петровић 2000).

Обележје консонантност групише, с једне стране, опструенте, ликвиде и назале, а с друге стране - вокале и полувокале. На овај начин би се поједини дијахронијски процеси могли формално представити, као што је измена $/ \mathrm{v} />/ \mathrm{u} /$ или $/ \mathrm{i} />/ \mathrm{j} /$. Као услов за вршење таквих измена могло би се спецификовати да се измене одигравају међу фонемама које имају обележје [-консонантност].

Да би се оценила корисност ових обележја у фонолошком систему српског језика, неопходно је размотрити какву улогу имају у фонотактичким правилима (које су комбинације консонаната могуће у наступу, а које у рубу) или у компензационим дуљењима, каква се дешавају испред сонаната у затвореним слоговима (као у примеру стар-ца, јазав-ца), јер ниједна класификација фонема нема пуно смисла ако не служи да се њоме прецизније опишу одређени процеси.

\section{ЛИТЕРАТУРА}

Барић et al. 1997: Eugenija Barić et al., Hrvatska gramatika, Zagreb: Školska knjiga. Батас 2018: Ана Батас, „Обележје короналност у српском језику”, Научни састанак слависта у Вукове дане, 47/3, 5-19.

Батас 2019: Ана Батас, „Начинска обележја у српском језику”, Научни састанак слависта у Вукове дане, 48/3, 5-18.

Белић 2000: Александар Белић, Универзитетска предавана из савременог српскохрватског језика. Библиографија радова Александра Белића, Изабрана дела Александра Белића 14. том (прир. Ж. Станојчић). Београд: Завод за уџбенике и наставна средства.

Бјорндал 2018: Christina Jean Bjorndahl, A Story of /v/: Voiced Spirants in the Obstruent-Sonorant Divide [PhD dissertation], Faculty of the Graduate School of Cornell University. <https://ecommons.cornell.edu/handle/1813/59623> 10. 8. 2020.

Брозовић 1968: Dalibor Brozović, „O fonološkom sustavu suvremenog standardnog hrvatskosrpskog jezika", Radovi Filozofskog fakulteta u Zadru. Razdio lingvističko-filološki, 7, Zadar: Filozofski fakultet u Zadru, 20-39.

Брозовић 1971: Dalibor Brozović, „O alofonskoj problematici u hrvatskoj ortoepiji”, Radovi Filozofskog fakulteta u Zadru. Razdio lingvističko-filološki, 10/9, Zadar: Filozofski fakultet u Zadru, 5-29.

Гусенховен/Џејкобс 2017: Carlos Gussenhoven, Haike Jakobs, Understanding Phonology. Fourth edition, Milton Park, Abingdon, Oxon; New York, NY: Routledge, [1998].

Јакобсон 1949/1964: Roman Jakobson, Selected Writings I. The Hague: Mouton. 
Јансен 2004: Wouter Jansen, Laryngeal Contrast and Phonetic Voicing: A Laboratory Phonology Approach to English, Hungarian, and Dutch [PhD dissertation], Groningen: University of Groningen, 2004. <http://irs.ub.rug.nl/ ppn/264415094> 10. 8. 2020.

Јансен 2007: Jansen Wouter, „Phonological 'voicing', phonetic voicing, and assimilation in English”, Language Science, 29/2-3, 276-293.

Клементс/Хјум 1996: G. N. Clements, Elizabeth V. Hume, „The internal organization of speech sounds", [in:] John A. Goldsmith (ed.) The Handbook of Phonological Theory. Blackwell Publishing.

Кристал 1999: Dejvid Kristal, Kembrička enciklopedija jezika, (red. R. Bugarski). Beograd: Nolit.

Муљачић 1964: Žarko Muljačić, Opća fonologija i fonologija suvremenog talijanskog jezika. Zagreb: Sveučilište u Zagrebu.

Паџет 2008: Jaye Padgett, „Glides, vowels, and features”, Lingua, 118, 1937-1955.

Петровић/Гудурић 2010: Драгољуб Петровић и Снежана Гудурић, Фонологија српскога језика, Београд - Нови Сад: Институт за српски језик САНУ, Београдска књига, Матица српска.

Петровић 2000: Драгољуб Петровић, „О репертоару ИДО у фонолошком систему стандарднога српског језика", Јужнословенски филолог, LVI, 789-802.

ПCA: Roman Jakobson, Gunnar Fant, Morris Halle, Preliminaries to Speech Analysis: The Distinctive Features and Their Correlates, $2^{\text {nd }}$ edition. MIT, Acoustics Lab., Technical Report No. 13, 1963 [1952].

Симић/Остојић 1996: Радоје Симић и Бранислав Остојић, Основи фонологије српског киижевног језика, Београд: Универзитет у Београду.

CПE: Noam Chomsky, Morris Halle, The Sound Pattern of English. New York, Evanston, and London: Harper \& Row, 1968.

Tраск 1996: R. L. Trask, A Dictionary of Phonetics and Phonology. London, New York: Routledge.

Трубецки 1958/2016: N. S. Trubeckoj, Načela fonologije (prev. V. Berić, A. Berić). Sremski Karlovci - Novi Sad: Izdavačka knjižarnica Zorana Stojanovića.

Xej3 2009: Bruce Hayes, Introductory Phonology, Wiley-Blackwell.

Хол 2007: T. A. Hall, „The segmental features”, [in:] Paul de Lacy (ed.) The Cambridge Handbook of Phonology. Cambridge University Press, 311-335. 
Ana S. Batas

\section{MAJOR-CLASS DISTINCTIVE FEATURES IN THE SERBIAN LANGUAGE}

\section{Summary}

In this paper the author discusses major-class features (the features that specify the major classes of sounds) such as [+/-sonorant], [+/-approximant], [+/-consonant], and [+/-syllabic $]$, and their applications in Serbian phonology. 